atmosphere from fires in the tropics, based on the FAO statistics for the period 1975-80. In Proceedings of the Third International Symposium on Fire Ecology, Springer-Verlag, New York, NY, USA: (in press).

Howlett, C.F. \& Zeitzer, G. (1986). The American Peace Movement: History and Historiography. American Historical Association, Washington, DC, USA: $64 \mathrm{pp}$.

IER (1990). Progress must be made in next decade to resolve key problems of 21 st Century. International Environment Reporter, 13 (April 11), pp. 159-60.

LapPe, F.K.M., Schurman, R. \& Danahar, K. (1987). Betraying the National Interest. Grove Press, New York, NY, USA: xi +180 pp., illustr.

LENWAY, S. A. (1988). Between war and commerce: economic sanctions as a tool of statecraft. International Organization, 42(2), pp. 397-426.

Levine, R. (1988). Trade vs. National Security: Section 232 Cases. Comparative Strategy, 7(2), pp. 133-42.

MansfiEld, E.D. (1988). The distribution of wars over time. World Politics, XLI (1), pp. 21-47.

Moreau, R. M. (1990). A nation at war with itself. Newsweek, May 28 , pp. 12-4.

MUELLER, J. (1989). Retreat from Doomsday: The Obsolescence of Major War. Basic Books, New York, NY, USA: xi + 336 pp., illustr.

Mullins Jr, A.F. (1987). Born Arming: Development and Military Power in New States. Stanford University Press, Stanford, California, USA: xvi + 147 pp., illustr.

Murdock, G.P. (1959). Africa: Its Peoples and Their Cultural History. McGraw-Hill, New York, NY, USA: xiii + 456 pp., illustr.

NYT (1989). Toxic site cleanup reported lagging. New York Times. Sept. 10, p. 32.

Perret, G. (1990). A Country Made by War: The Story of America's Rise to Power. Random House. New York, NY, USA: ix + 629 pp., illustr.

RASLER, K.A. \& THOMPSON, W.R. (1985). War making and state making: governmental expenditures, tax revenues, and global wars. American Political Science Review, 79(2), pp. 491-507.

RENNER, M.G. (1991). War on Nature. World Watch, 4(3), pp. 18-25.

RUPESINGHE, K. (1988). Ethnic conflicts in South Asia: the case of Sri Lanka and the Indian Peace-keeping Force (IPKF). Journal of Peace Research, 25(4), pp. 337-50.

SHAw, R. P. (1989). Rapid population growth and environmental degradation: ultimate versus proximate factors. Environmental Conservation, 16(3), pp. 199-208, 3 figs, box, and table.
SHAW, R.P. (1991). Shackles on international environmental development and cooperation. International Environment Reporter, 14 (January 30 ), pp. 53-8.

Shaw, R. P. \& Wong, Y. (1989). Genetic Seeds of Warfare: Evolution, Nationalism and Patriotism. Unwin Hyman/ Routledge, London, England, UK: $x+274$ pp., illustr.

SingER, J. D. (1981). Accounting for international war: the state of the discipline. Journal of Peace Research, 18(1), pp. 1-18.

Stavenhagen, R. (1987). Ethnocide or ethnodevelopment. Development (1), pp. 74-8.

WCED (1987). Our Common Future. (World Commission on Environment and Development.) Oxford University Press, Oxford, England, UK: $x v+400$ pp., illustr.

WESTING, A.H. (Ed.) (1985). Explosive Remnants of War: Mitigating the Environmental Effects. Taylor \& Francis, London, England, UK: $x v i+141$ pp., illustr.

Westing, A.H. (1988). The military sector vis-a-vis the environment. Journal of Peace Research, 25(3), pp. 257-64.

Westing, A.H. (Ed.) (1990). Environmental Hazards of War: Releasing Dangerous Forces in an Industrialized World. Sage Publications, London, England, UK: xvi +96 pp.

WeSTING, A.H. (1992), Environmental refugees: a growing category of displaced persons. Environmental Conservation, 19(3), pp. 201-7 with 4 tables.

WingleE, P. (1989). Agricultural trade policies of industrial countries. Finance and Development, 26(1), pp. 9-11.

WinTERBOTTOM, R. (1990). Taking stock: the Tropical Forestry Action Plan after five years. World Resources Institute Publications Brief, World Resources Institute, Washington, DC, USA: July, 4 pp.

WONG, Y. (1993). Impotence and Intransigence: State Behaviour in the Throes of Deepening Global Crises, An Evolutionary Perspective. Horizon Pacific International, Vancouver, $\mathrm{BC}$, Canada: 29 pp. (mimeogr.)

WORLD BANK (1987). World Development Report 1987. World Bank, Washington, DC, USA: xii + 285 pp., illustr.

WORLD BANK (1992). World Development Report 1992. World Bank, Washington, DC, USA: xi + $308 \mathrm{pp}$, illustr.

WRI (1992). World Resources : 1992-93. World Resources Institute and Oxford University Press, Oxford, England, UK: xiv +400 pp., illustr.

ZANOYAN, V. (1988). Out of the Gulf's rubble. The Economist, August 20, pp. 55-6.

ZIETZ, J. \& VALDEZ, A. (1986). Costs of Protectionism in Developing Countries: An Analysis of Selected Agricultural Products. World Bank Working paper No. 769, World Bank, Washington, DC, USA: viii + $90 \mathrm{pp}$.

\title{
ERRATA
}

\section{Wildlife and Reclamation Ecology: Rabbit Middens on Seeded Limestone Quarry-spoil}

\author{
by
}

Dr JEAN M. Dixon

$\&$

Dr DAVID J. HAMBLER

(Environmental Conservation, Vol. 20, Nr 1, pp. 65-73, Spring 1993)

\section{ERRATA}

Table I, p. 69.

(i) In column 4: for $1.2 *$ substitute $0.82 * \S$.

(ii) In penultimate column: substitute 1.48 for 0.148 .

(iii) In last column: for $2.5 \S$ substitute $0.85 * \S$.

(iv) Last line should begin: ${ }^{*}=$ published data from Watt (1981); $\S=$ calculated from $\mathrm{PO}_{4}$ given.

p. 70

In last paragraph of 'Derived Data...' substitute 2.5 for 2.9 . 